\title{
Tingkat Pengetahuan Ibu Primigravida Tentang Posisi Melahirkan di RB. Medika Utama Balongbendo
}

\author{
Uky Nofitasari', Hj.Kusindijah² \\ 1. Mahasiswa Program Studi D-III Kebidanan Universitas PGRI Adi Buana Surabaya \\ 2. Tenaga Pengajar Program Studi D-III Kebidanan Universitas PGRI Adi Buana Surabaya
}

\begin{abstract}
ABSTRAK
Persalinan adalah saat yang menegangkan dan dapat menggugah emosi atau bahkan dapat menjadi saat yang menyakitkan dan menakutkan bagi ibu. Upaya untuk mengatasi hal tersebut sebaiknya dilakukan melalui asuhan sayang ibu selama persalinan, seperti memberikan dukungan emosional, memberikan cairan dan nutrisi, keleluasaan untuk menggunakan kamar mandi secara teratur, pencegahan infeksi, dan membantu pengaturan posisi ibu. Berdasarkan masalah yang ditemukan di RB. Medika Utama Balongbendo yaitu mayoritas ibu primigravida tidak kooperatif saat persalinan. Ketika petugas menyarankan ibu untuk mengubah posisi saat persalinan, ibu tidak menghiraukan dan enggan untuk mengubah posisi. Sehingga menyebabkan persalinan lama, rasa sakit yang semakin dirasakan dan robekan perineum yang lebih luas. Penelitian ini bertujuan untuk mengetahui tingkat pengetahuan ibu primigravida tentang posisi melahirkan.

Metode penelitian yang digunakan adalah deskriptif kuantitatif dan pengambilan sampelnya menggunakan teknik sampling jenuh. Sampel dalam penelitian ini berjumlah 32 responden. Instrumen dalam penelitian ini adalah kuesioner tertutup. Cara pengumpulan data menggunakan data primer dan data sekunder. variabel dalam penelitian ini adalah variabel tunggal yaitu tingkat pengetahuan ibu primigravida tentang posisi melahirkan. Pengolahan data dan analisa data dalam penelitian ini menggunakan persentase.

Berdasarkan hasil penelitian, dari 32 responden didapatkan ibu primigravida yang memiliki pengetahuan baik sebanyak 3 responden (9\%), cukup sebanyak 17 responden (53\%) dan kurang sebanyak 12 responden (38\%).

Dari hasil tersebut dapat disimpulkan bahwa tingkat pengetahuan ibu primigravida tentang posisi melahirkan di RB. Medika Utama Balongbendo pada tingkat cukup. Diharapkan penelitian ini dapat memberikan informasi kepada ibu primigravida tentang posisi melahirkan sehingga ibu lebih siap untuk menghadapi persalinan dan kooperatif saat persalinan.
\end{abstract}

Kata Kunci : Tingkat Pengetahuan, Ibu Primigravida, Posisi melahirkan

\section{PENDAHULUAN}

Angka Kematian Ibu (AKI) merupakan barometer pelayanan kesehatan ibu disuatu negara. Berdasarkan Survei Demografi dan Kesehatan Indonesia (SDKI) tahun 2003, Angka Kematian Ibu (AKI) di Indonesia adalah 307 per 100.000 kelahiran hidup . Bila mengacu pada ekstrapolasi Biro Pusat Statistik maka kecenderungan penurunan Angka Kematian Ibu (AKI) telah mengarah jalur yang diinginkan yaitu 265/100.000 kelahiran hidup pada tahun 2006 dan 248/100.000 kelahiran hidup pada tahun 2007 walaupun interpretasi secara global menyebutkan bahwa perjalanan menuju target Millenium Development Goal's (MDG's) masih diluar jalurnya. (Dep.Kes.RI, 2008). Kejadian kematian ibu maternal paling banyak adalah sewaktu bersalin sebesar 49,5\%, kematian waktu hamil $26 \%$, dan pada waktu nifas $24 \%$. (Dinkes, 2011).

Persalinan adalah saat yang menegangkan dan dapat menggugah emosi ibu dan keluarganya atau bahkan dapat menjadi saat yang menyakitkan dan menakutkan bagi ibu. Upaya untuk mengatasi gangguan emosional dan pengalaman yang menegangkan tersebut sebaiknya dilakukan melalui asuhan sayang ibu selama persalinan dan proses kelahiran bayinya. (Dep.Kes.RI, 2008).

Asuhan sayang ibu adalah asuhan dengan prinsip saling menghargai budaya, kepercayaan dan keinginan dari pasien dalam hal ini ibu. (Sumarah, dkk, 2009). Asuhan sayang ibu selama persalinan termasuk memberikan dukungan emosional, memberikan cairan dan nutrisi, keleluasaan untuk menggunakan kamar mandi secara teratur, pencegahan infeksi, dan 
membantu pengaturan posisi ibu. (Dep.Kes.RI, 2008).

Selama ini banyak ibu hamil beranggapan posisi melahirkan hanya berbaring (litotomi) atau setengah duduk. Padahal orang zaman dahulu mempunyai kebiasaan melahirkan dengan cara jongkok atau berdiri. Semua posisi ada kelebihan dan kekurangannya. (Chomaria, Nurul, 2012).

Dalam kehamilan ibu sudah aktif berproses dalam menghadapi persalinan misalnya ibu sudah senam, latihan jalan-jalan, jongkok, ibu akan menggunakan posisi tidur senyaman mungkin yang telah dilakukan selama hamil seperti jongkok, merangkak atau berdiri. Hal ini akan meningkatkan keinginan merubah posisi pada saat persalinan karena sudah dilatih pada saat hamil. (Sumarah, dkk, 2009).

Banyak ibu hamil merasakan bahwa persalinan merupakan proses yang cukup menakutkan untuk dilalui namun ada juga ibu hamil yang mengatakan bahwa proses melahirkan adalah merupakan kodrat wanita yang mudah untuk dilalui. Mudah atau sulitnya suatu proses persalinan tergantung oleh banyak faktor, salah satunya adalah ibu hamil cukup pengetahuan untuk menghadapi persalinan. (Hartuti T, 2010). Beberapa faktor yang mempengaruhi pengetahuan ibu hamil tentang posisi melahirkan diantaranya pendidikan, mass media/informasi, umur, pengalaman, pekerjaan, lingkungan dan social budaya.

(http://stikeskusumahusada.ac.id/digilib/files/dis k1/2/01-gdl-wildaaru ni-64-1-wildaar-5.pdf,).

Berdasarkan masalah yang ditemukan di RB. Medika Utama Balongbendo yaitu mayoritas ibu primigravida tidak kooperatif saat persalinan. Ketika petugas menyarankan ibu untuk mengubah posisi saat persalinan, ibu tidak menghiraukan dan enggan untuk mengubah posisi. Sehingga berdampak pada proses persalinannya, seperti persalinan lama, rasa sakit yang semakin banyak dan robekan perineum yang lebih luas. Setelah dilakukan evaluasi, hal tersebut terjadi karena ibu hanya mengetahui posisi melahirkan itu dengan tidur dan mengangkat kedua kaki dan hanya beberapa saja yang pernah mendengar tentang macam-macam posisi melahirkan namun ibu belum pernah melakukan atau mencoba posisiposisi melahirkan karena ibu belum memiliki pengalaman melahirkan sebelumnya.

Berdasarkan uraian diatas, peneliti tertarik untuk melakukan penelitian mengenai "Tingkat
Pengetahuan Ibu Primigravida Tentang Posisi Melahirkan diRB. Medika Utama Balongbendo". Berdasarkan latar belakang masalah di atas maka tujuan penelitian ini sebagai berikut : a.) Tujuan umum, Mendapatkan gambaran bagaimana tingkat pengetahuan ibu primigravida tentang posisi melahirkan; b.) Tujuan khusus untuk mengidentifikasi tingkat pengetahuan ibu primigravida tentang posisi melahirkan, tingkat pengetahuan ibu primigravida tentang posisi melahirkan berdasarkan pendidikan, tingkat pengetahuan ibu primigravida tentang posisi melahirkan berdasarkan pekerjaan, tingkat pengetahuan ibu primigravida tentang posisi melahirkan berdasarkan umur.

\section{BAHAN DAN METODE}

Desain penelitian ini mengunakan desain penelitian deskriptif kuantitatif. Penelitian deskriptif merupakan suatu penelitian yang bertujuan untuk mendiskripsikan (memaparkan) peristiwa-peristiwa penting yang terjadi pada masa kini. Deskripsi peristiwa dilakukan secara sistematis dan lebih menekankan pada data faktual daripada penyimpulan. Fenomena disajikan secara apa adanya tanpa manipulasi dan peneliti tidak mencoba menganalisis bagaimana dan mengapa fenomena tersebut bisa terjadi, oleh karena itu penelitian jenis ini tidak memerlukan adanya suatu hipotesis. (Nursalam, 2011). Kuantitatif yaitu data yang dipaparkan dalam bentuk angka-angka. (Arikunto, Suharsimi, 2010).

Menurut Manuaba, Ida Bagus Gde (2010), gravida adalah wanita yang sedang hamil, dan primigravida adalah wanita yang hamil untuk pertama kali.

Dalam penelitian ini peneliti mengambil gambaran tingkat pengetahuan tentang posisi melahirkan dengan subjek adalah ibu primigravida trimester III, pada tanggal 15 April s/d 15 Juni 2013 di RB. Medika Utama Balongbendo. Sampel yang diteliti dalam penelitian ini adalah ibu primigravida Trimester III di RB. Medika Utama Balongbendo pada bulan April sampai Juni 2013 sebanyak 32 orang. Dalam penelitian kebidanan, kriteria sampel meliputi kriteria inklusi dan kriteria eksklusi, dimana kriteria tersebut menentukan dapat atau tidaknya sampel tersebut digunakan. (Hidayat, A. Azis Alimul, 2010).

Kriteria inklusi dalam penelitian ini adalah : a.) Ibu primigravida trimester III dengan kehamilan fisiologis; b.) lbu primigravida 
trimester III yang bersedia menjadi responden; c.) Ibu primigravida trimester III yang bisa bacatulis. Dan kriteria ekslusi dalam penelitian ini adalah : a.) Ibu primigravida trimester III dengan kehamilan patologis; b.) lbu primigravida trimester III yang tidak bersedia menjadi responden, c.) lbu primigravida trimester III yang tidak bisa baca-tulis.

Teknik sampling yang digunakan dalam penelitian ini adalah sampling jenuh. Sampling jenuhyaitu teknik penentuan sampel bila semua anggota populasi menjadi sampel. Cara ini dilakukan bila populasinya kecil, seperti bila sampelnya kurang dari tiga puluh maka anggota populasi tersebut diambil seluruhnya untuk dijadikan sampel penelitian. (Hidayat, A. Azis Alimul, 2010). Pengambilan sampel dalam penelitian ini dengan cara meneliti semua responden yang memenuhi kriteria inklusi.

Variabel dalam penelitian ini adalah variabel tunggal yaitu pengetahuan ibu primigravida tentang posisi melahirkan. Definisi operasional variabel ditentukan berdasarkan parameter yang dijadikan ukuran dalam penelitian. Definisi operasional ini penting dan diperlukan agar pengukuran variabel atau pengumpulan data (variabel) itu konsisten antara sumber data (responden) yang satu dengan responden yang lain. Disamping variabel harus didefinisi operasionalkan juga perlu dijelaskan cara atau metode pengukuran hasil ukur atau kategorinya, serta skala pengukuran yang digunakan. Untuk memudahkan, biasanya definisi operasional itu disajikan dalam bentuk "matrix" yang terdiri dari kolom-kolom.

\section{HASIL DAN PEMBAHASAN}

Hasil penelitian ini menyajikan hasil pengumpulan data dari lembar kuesioner yang telah di isi oleh responden yang meliputi karakteristik responden dan pengetahuan tentang posisi melahirkan. Responden dalam penelitian ini adalah ibu primigravida Trimester III di RB. Medika Utama Balongbendo dengan jumlah 32 responden.

Pada penyajian hasil dibagi dalam tiga bagian yaitu : 1.) Data umum menampilkan karakteristik responden yaitu pendidikan, pekerjaan dan umur; 2.) Data khusus meliputi tingkat pengetahuan ibu primigravida tentang posisi melahirkan dan tingkat pengetahuan ibu primigravida tentang posisi melahirkan berdasarkan pendidikan, pekerjaan dan umur.

\section{Data Umum}

Data yang menyangkut karakteristik dari responden dan diuraikan sebagai berikut :

\begin{tabular}{cccc}
\hline NO & Pendidikan & $\begin{array}{c}\text { frekuensi } \\
(\mathbf{f})\end{array}$ & $\begin{array}{c}\text { Persentas } \\
\mathbf{e} \\
(\%)\end{array}$ \\
\hline 1 & SD & 0 & 0 \\
2 & SMP & 14 & 44 \\
3 & SMA & 15 & 47 \\
4 & $\begin{array}{c}\text { Perguruan } \\
\text { Tinggi }\end{array}$ & 3 & 9 \\
\hline & Jumlah & 32 & 100 \\
\hline
\end{tabular}

Tabel 1 - Distribusi frekuensi karakteristik responden berdasarkan pendidikan di RB. Medika Utama Balongbendo

Dari tabel 1 dapat diketahui bahwa dari 32 responden tidak ada yang berpendidikan SD, 14 responden (44\%) berpendidikan SMP, 15 responden $(47 \%)$ berpendidikan SMA dan 3 responden $(9 \%)$ berpendidikan perguruan tinggi.

\begin{tabular}{|c|c|c|c|}
\hline NO & Pekerjaan & $\begin{array}{c}\text { Frekuensi } \\
\text { (f) }\end{array}$ & $\begin{array}{c}\text { Persentase } \\
(\%)\end{array}$ \\
\hline 1 & $\begin{array}{c}\text { Tidak } \\
\text { Bekerja }\end{array}$ & 15 & 47 \\
\hline 2 & Swasta & 14 & 44 \\
\hline \multirow[t]{2}{*}{3} & PNS & 3 & 9 \\
\hline & Jumlah & 32 & 100 \\
\hline
\end{tabular}

Tabel 2 - Distribusi frekuensi karakteristik responden berdasarkan pekerjaan di RB. Medika Utama Balongbendo

Dari tabel 2 dapat diketahui bahwa dari 32 responden terdapat 15 responden (47\%) ibu tidak bekerja , 14 responden (44\%) bekerja

sebagai pekerja swasta dan 3 responden (9\%) bekerja sebagai PNS.

\begin{tabular}{cccc}
\hline NO & $\begin{array}{c}\text { Umur } \\
\text { (tahun) }\end{array}$ & $\begin{array}{c}\text { Frekuensi } \\
(\mathbf{f})\end{array}$ & $\begin{array}{c}\text { Persentase } \\
(\%)\end{array}$ \\
\hline 1 & $\begin{array}{c}<20 \\
\text { tahun }\end{array}$ & 14 & 44 \\
2 & $\begin{array}{c}20-30 \\
\text { tahun } \\
>30 \\
\text { tahun }\end{array}$ & 17 & 53 \\
3 & 1 & 3 \\
\hline & Jumlah & 32 & 100 \\
\hline
\end{tabular}

Tabel 3 - Distribusi frekuensi karakteristik responden berdasarkan umur di RB. Medika Utama Balongbendo 
Dari table 3 didapatkan bahwa dari 32 responden terdapat 14 responden (44\%) berumur $<20$ tahun, 17 responden (53\%) yang berumur 20-30 tahun dan 1 responden $(3 \%)$ berumur $>30$ tahun.

\section{Data Khusus}

Pembahasan mengenai tingkat pengetahuan ibu primigravida tentang posisi melahirkan dan tingkat pengetahuan ibu primigravida berdasarkan karakteristik responden yang meliputi pendidikan, pekerjaan dan umur.

\begin{tabular}{cccc}
\hline NO & Pengetahuan & $\begin{array}{c}\text { Frekuensi } \\
(\mathbf{f})\end{array}$ & $\begin{array}{c}\text { Persentase } \\
(\%)\end{array}$ \\
\hline 1 & Baik & 3 & 9 \\
2 & Cukup & 17 & 53 \\
3 & Kurang & 12 & 38 \\
\hline & Jumlah & 32 & 100 \\
\hline
\end{tabular}

Tabel 4 - Distribusi frekuensi tingkat pengetahuan ibu primigravida tentang posisi melahirkan di RB. Medika Utama Balongbendo

Tabel 4 dapat diketahui bahwa tingkat pengetahuan ibu primigravida tentang posisi melahirkan di RB. Medika Utama Balongbendo dari 32 responden terdapat sebanyak 3 responden (9\%) dengan pengetahuan baik, 17 responden (53\%) dengan pengetahuan cukup dan sebanyak 12 responden (38\%) dengan pengetahuan kurang.
Tabel 5 - Distribusi frekuensi tingkat pengetahuan ibu primigravida tentang posisi melahirkan berdasarkan pendidikan di RB. Medika Utama Balongbendo

Berdasarkan distribusi frekuensi pada tabel 5 dapat diketahui bahwa : a.) Tidak ada responden yang berpendidikan SD; b.) Responden yang memiliki tingkat pengetahuan baik adalah responden dengan pendidikan perguruan tinggi yaitu sebanyak 3 responden $(9 \%)$; c.) Responden yang memiliki

\begin{tabular}{c|c|c|c|c|c|c|c|c}
\hline \multirow{2}{*}{$\begin{array}{c}\text { Pekerja } \\
\text { an }\end{array}$} & \multicolumn{5}{|c|}{ Pengetahuan } & \multicolumn{3}{c}{ Total } \\
\cline { 2 - 8 } & \multicolumn{2}{|c|}{ Baik } & \multicolumn{2}{|c|}{ Cukup } & \multicolumn{2}{c|}{ Kurang } & \multicolumn{2}{c}{} \\
\cline { 2 - 9 } & $\mathbf{f}$ & $\%$ & $\mathbf{f}$ & $\%$ & $\mathbf{f}$ & $\%$ & $\mathbf{f}$ & $\%$ \\
\hline $\begin{array}{c}\text { Tidak } \\
\text { Bekerja }\end{array}$ & 0 & 0 & 5 & 16 & 10 & 31 & 15 & 47 \\
Swasta & 0 & 0 & 12 & 38 & 2 & 6 & 14 & 44 \\
PNS & 3 & 9 & 0 & 0 & 0 & 0 & 3 & 9 \\
\hline TOTAL & 3 & 9 & 17 & 53 & 12 & 38 & 32 & 100 \\
\hline
\end{tabular}

pengetahuan cukup adalah responden dengan pendidikan SMP yaitu sebanyak 2 responden (6\%) dan 15 responden (47\%) berpendidikan SMA; d.) Responden yang memiliki tingkat pengetahuan kurang adalah responden yang berpendidikan SMP yaitu sebanyak 12 responden (38\%).

Tabel 6 - Distribusi frekuensi tingkat pengetahuan ibu primigravida tentang posisi melahirkan berdasarkan pekerjaan di RB. Medika Utama Balongbendo

\begin{tabular}{|c|c|c|c|c|c|c|c|c|}
\hline \multirow{3}{*}{ Pendidikan } & \multicolumn{6}{|c|}{ Pengetahuan } & \multirow{2}{*}{\multicolumn{2}{|c|}{$\begin{array}{l}\text { Berdasarkan distribusi frekuensi pada table } \\
\text { Toqaplapat diketahui bahwa : a.) Responden yang } \\
\text { memiliki pengetahuan baik adalah bekerja }\end{array}$}} \\
\hline & \multicolumn{2}{|c|}{ Baik } & \multicolumn{2}{|c|}{ Cukup } & \multicolumn{2}{|c|}{ Kurang } & & \\
\hline & $\mathbf{f}$ & $\%$ & f & $\%$ & $f$ & $\%$ & f & $\begin{array}{llll}\text { sebagal } & \text { PINS yaltu sebanyak } 3 \text { responden } \\
(9 \%) ; & \text { b.) } & \text { Responden yang memiliki }\end{array}$ \\
\hline SD & 0 & 0 & 0 & 0 & 0 & 0 & 0 & $\begin{array}{l}\text { pengetahuan cukup adalah ibu yang tidak } \\
\text { bekerja yaitu sebanyak } 5 \text { responden (16\%), dan }\end{array}$ \\
\hline SI & 0 & 0 & 2 & 6 & 12 & 38 & 14 & $\begin{array}{l}\text { betgerja sebagai pekerja swasta yaitu seban } \\
12 \text { responden (38\%); c.) Responden y }\end{array}$ \\
\hline SMA & 0 & 0 & 15 & 47 & 0 & 0 & 15 & mømiliki pengetahuan kurang, adalah ibu y \\
\hline $\begin{array}{l}\text { Perguruan } \\
\text { Tinggi }\end{array}$ & 3 & 9 & 0 & 0 & 0 & 0 & 3 & $\begin{array}{l}\text { tidak bekerja yaitu sebanyak } 10 \text { respon } \\
(39 \%) \text {, dan bekerja sebagai pekerja sw }\end{array}$ \\
\hline TOTAL & 3 & 9 & 17 & 53 & 12 & 38 & 32 & yaitu sel \\
\hline
\end{tabular}




\begin{tabular}{|c|c|c|c|c|c|c|c|c|}
\hline \multirow{3}{*}{$\begin{array}{c}\text { Umur } \\
\text { (tahun) }\end{array}$} & \multicolumn{6}{|c|}{ Pengetahuan } & \multirow{2}{*}{\multicolumn{2}{|c|}{ Total }} \\
\hline & \multicolumn{2}{|c|}{ Baik } & \multicolumn{2}{|c|}{ Cukup } & \multicolumn{2}{|c|}{ Kurang } & & \\
\hline & $\mathbf{f}$ & $\%$ & $f$ & $\%$ & $\mathbf{f}$ & $\%$ & $\mathbf{f}$ & $\%$ \\
\hline $\begin{array}{c}<20 \\
\text { tahun } \\
20-\end{array}$ & 0 & 0 & 2 & 6 & 12 & 38 & 14 & 44 \\
\hline $\begin{array}{c}\text { 30tahu } \\
\text { n }\end{array}$ & 2 & 6 & 15 & 47 & 0 & 0 & 17 & 53 \\
\hline $\begin{array}{c}>30 \\
\text { tahun }\end{array}$ & 1 & 3 & 0 & 0 & 0 & 0 & 1 & 3 \\
\hline TOTAL & 3 & 9 & 17 & 53 & 12 & 38 & 32 & 100 \\
\hline
\end{tabular}

Tabel 7 - Distribusi frekuensi tingkat pengetahuan ibu primigravida tentang posisi melahirkan berdasarkan umur di RB. Medika Utama Balongbendo

Berdasarkan distribusi frekuensi pada table 7 dapat diketahui bahwa : a.) Responden yang memiliki tingkat pengetahuan baik adalah responden dengan umur 20-30 tahun yaitu sebanyak 2 responden (6\%), dan berumur $>30$ tahun sebanyak 1 responden (3\%); b.) Responden yang memiliki pengetahuan cukup adalah responden yang berumur $<20$ tahun yaitu sebanyak 2 responden (6\%) dan berumur 20-30 tahun sebanyak 15 responden (47\%); c.) Responden yang memiliki tingkat pengetahuan kurang adalah responden dengan umur $<20$ tahun yaitu sebanyak 12 responden (38\%).

\section{SIMPULAN DAN SARAN}

Penelitian ini dilakukan di RB. Medika Utama Balongbendo dengan responden yang berjumlah 32 responden. Dari hasil penelitian tingkat pengetahuan ibu primigravida tentang posisi melahirkan di RB. Medika Utama Balongbendo dapat disimpulkan bahwa : 1.) Tingkat pengetahuan ibu primigravida tentang posisi melahirkan di RB. Medika Utama Balongbendo termasuk dalam kategori cukup; 2.) Tingkat pengetahuan ibu primigravida tentang posisi melahirkan di RB. Medika Utama Balongbendo ditinjau dari pendidikan adalah terbanyak dalam kategori cukup pada responden dengan pendidikan SMA; 3.) Tingkat pengetahuan ibu primigravida tentang posisi melahirkan di RB. Medika Utama Balongbendo ditinjau dari pekerjaan adalah terbanyak dalam kategori cukup didapatkan pada responden yang bekerja swasta; 4.) Tingkat pengetahuan ibu primigravida tentang posisi melahirkan di RB. Medika Utama Balongbendo ditinjau dari umur terbanyak dalam kategori cukup terdapat pada responden usia $20-30$ tahun.

Berdasarkan hasil penelitian mengenai tingkat pengetahuan ibu primigravida tentang posisi melahirkan di RB. Medika Utama

Balongbendo, maka saran yang dapat peneliti sampaikan adalah : 1.) Bagi Institusi, a.) RB. Medika Utama Balongbendo, diharapkan hasil penelitian ini dapat digunakan sebagai acuan dan masukan dalam upaya meningkatkan mutu pelayanan dengan peningkatan pengetahuan ibu primigravida melalui penyuluhan dan pelatihan khususnya tentang posisi melahirkan; b.) Pendidikan, diharapkan penelitian ini dapat menambah bahan bacaan atau referensi tentang pengetahuan ibu primigravida tentang posisi melahirkan; 2.) Bagi Responden, Hasil penelitian ini diharapkan dapat memberikan informasi kepada ibu primigravida trimester III tentang posisi melahirkan, sehingga ibu lebih siap untuk menghadapi persalinan nantinya dan kooperatif saat persalinan; 3.) Bagi peneliti selanjutnya, diharapkan bagi peneliti selanjutnya hasil penelitian ini dapat bermanfaat dan dapat digunakan sebagai bahan pembanding bagi penelitian-penelitian selanjutnya dan juga dapat mengembangkan variabel penelitian dan sampel penelitian lebih banyak.

\section{DAFTAR PUSTAKA}

Arikunto, Suharsimi. 2010. Prosedur Penelitian Suatu Pendekatan Praktik. Jakarta : Rineka Cipta

Arunindya, Wilda. 2012. Tingkat Pengetahuan Ibu Hamil Tentang Posisi Meneran Di BPS Wiji Suryanti Palur Sukoharjo. KTI. Surakarta : Sekolah Tinggi IImu Kesehatan Kusuma Husada. Diakses melalui

A.Wawan dan Dewi M. 2011. Teori \& Pengukuran Pengetahuan, Sikap, DanPerilaku Manusia.Yogyakarta : Nuha Medika

Departemen Kesehatan Republik Indonesia. 2003. Asuhan Persalinan Normal. Jakarta : Jaringan Nasional Pelatihan Klinik Kesehatan Republik Indonesia. 2008. Asuhan Persalinan Normal. Jakarta : Jaringan Nasional Pelatihan Klinik Kesehatan Republik Indonesia.

Dinkes RI, 2011. AKI Di Indonesia. http:www.dinkes.aki.html. Diakses tanggal 05 Maret 2013 pukul 13.50 WIB 
Hartuti T. 2010. Panduan Ibu Hamil Melahirkan \& Merawat Bayi. Jakarta : UBA Press

Hasan, Iqbal. 2010. Analisis Data Penelitian dengan Statistik. Jakarta : Bumi Aksara

Hidayat, A. Azis Alimul. 2010. Metode Penelitian Kebidanan dan Teknik Analisis Data. Jakarta : Salemba Medika

Manuaba, Ida Bagus Gde. 2010. IImu Kebidanan, Penyakit Kandungan, dan $K B$. Jakarta : EGC

Notoatmodjo, Soekidjo. 2010. Metodologi Penelitian Kesehatan. Jakarta : Rineka Cipta

Nursalam, 2011. Konsep dan Penerapan Metodologi Penelitian IImu Keperawatan Pedoman Skripsi, Tesis, Dan Instrumen Penelitian Keperawatan. Jakarta : Salemba Medika

Prawirohardjo, Sarwono. 2010. Buku Acuan Nasional Pelayanan Kesehatan Maternal Dan Neonatal. Jakarta :Yayasan Bina Pustaka Sarwono Prawirohardjo

Sumarah, dkk. 2009. Perawatan Ibu Bersalin. Yogyakarta : Fitramaya 